\title{
The necessity of effective teaching of English at all levels of education in Nigeria
}

\author{
Sunday Abraham Unubi \\ Kogi State University, Anyigba, Nigeria \\ unubi4u@gmail.com
}

\section{ARTICLE INFO}

\section{Article history}

Received 23 December 2019

Revised 14 March 2020

Accepted 16 August 2020

Available Online 15 January 2021

\section{Keywords}

English

teaching

effective teaching

education

\begin{abstract}
Since language is dynamic, and teaching is a dynamic tool of instructing and training someone (the learner) for desired change in their lives, behaviors, experiences, and statuses, it also requires a dynamic and an experienced mind to carry it out. In its methodology, the study adopted both the primary and secondary sources of data gathering technique. Observational examination of both teachers and learners of the English language constituted the primary source while extant material dealing with the teaching and learning of English comprised the secondary data. The observation mainly bordered on phonetics and phonology, that is, how some Nigerian teachers of English realize or articulate some sounds and words of English, which in turn has impacted negatively on the learner. These sounds and words are divided into two groups - A and B, and group $\mathrm{A}$ is further divided into vowel and consonant sounds. We also presented the charts of the vowels and consonants of English to guide us in our analysis. The result of this investigation showed that mother tongue interference is the main factor responsible, and that teachers need to do extra work on themselves for satisfactory and positive learning outcomes on the learners, which is a direct consequence of effective teaching.
\end{abstract}

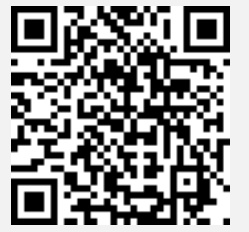

This is an open access article under the CC-BY-SA license.

\section{Introduction}

Since the advent of the English language in Nigeria following colonization, there has been reasonable progress in both teaching and learning of the language but more needs to be done, especially on the aspect of teaching because if a learner must be equipped with all the technical linguistic expertise that culminates in the mastery of this language, the vehicle that delivers the goods is teaching. And if teaching is not very effective to generate change in the learning behavior of the learner, then something is, indeed, wrong somewhere.

According to linguistic history, the English language is a member of the West Germanic branch of the Indo-European family of languages. This expansive family includes most of the European languages spoken today. The Indo-European family includes several major branches, which includes Latin and the modern Romance languages; the Germanic languages; the Indo-Iranian languages, including Hindi and Sanskrit; the Slavic languages; the Baltic languages of Latvian and Lithuanian; the Celtic languages; and the Greek. By and large, the English language has its origin in northwestern Germany, from where it was brought to England by the Anglo-Saxons. At the time this happened, approximately 1,500 - 1,600 years ago, English was very different from what it is today, in grammar, vocabulary and pronunciation. This difference is indicated by the use of the expression 
'Old English' (or, sometimes, 'Anglo-Saxon') to refer to the earlier form of the language. Since then, Old English has evolved into the language of today. This evolution is regarded generally as falling into three main stages or periods such as the Old English: 500 to about 1100 AD; the Middle English: about 1100 - 1500 AD; and the Modern English: 1500 - present day (Wilton, 2001, as cited in Unubi \& Bello, 2019, and Unubi \& Yusuf, 2017).

\subsection{Literature Review}

The review of literature in this section will concentrate on the important concepts of this research, which also constitute the keywords of this research. These include English, teaching, effective teaching, and education. This will be done succinctly because we are already familiar with these terms. In addition, empirical review of works carried out by other researchers in time past that are related to this subject will be done.

\subsection{Conceptual Review}

English, as mentioned afore, belongs to the West Germanic branch of the Indo-European family of languages. The language is primarily spoken in Britain and other European countries. However, it found its way into Nigeria when economic trade began between the Europeans and African countries as far back as centuries ago. According to history, the English language came into Nigeria when two English men: Nicholas Lambert and Thomas Wyndham, who were regarded as the first sailors, arrived the coastal region of Nigeria in fifteenth century (Idowu, 2019). As time went on, more Europeans such as the Portuguese, the Spanish as well as the Americans started coming in their number for both missionary and economic activities. And to be at par with these Europeans in terms of communication, early Nigerian business men and women started learning the language not only for business activities but also to serve as middlemen and women as well as interpreters. Furthermore, the subsequent colonization of Nigeria by the British made the English language more popular in the country, and by implication became the nation's lingua-franca, official language and the language of instruction or teaching and learning among others. As it retains its position of a lingua-franca, an official language, and a language of instruction, pupils are expected to pass it with a good grade at Common Entrance Examination, secondary school students must have at least a credit pass as a requirement for admission into higher institutions of learning, while students in tertiary institutions are expected to pass it in General Studies before graduation, and should be able to communicate effectively in it both before and after graduation, as the case may be.

Teaching has been defined variously by many scholars in education in line with how they view it. To Unubi \& Akonti (2017), teaching means inducing understanding in the learner, which also goes further to produce change in learning behavior or outcome that is satisfactory to the learner, the teacher and even the guardians of the learner. Smith (2018) defined teaching as the process of attending to people's needs, experiences and feelings, and intervening so that they learn particular things, and go beyond the given. According to him, this intervention commonly takes take the form of questioning, listening, giving information, explaining some phenomenon, demonstrating a skill or process, testing understanding and capacity, and facilitating learning activities such as note taking, discussion, assignment writing, simulations and practice. Teaching can also be defined using its characteristic nature as follows: (i) it is a complete social process; (ii) it is giving information; (iii) it is an interactive process; (iv) it is a process of development and learning; (v) it causes a change in behavior; (vi) it is an art as well as a science; (vii) it is face to face encounter; (viii) it is observable, measurable and modifiable; (ix) it is a skilled occupation; (x) it facilitates learning; (xi) it is both conscious and an unconscious process; (xii) it is from memory level to reflective level; (xiii) it is a continuum of training, conditioning, instruction, and indoctrination; and (xix) it should begin from the known to the unknown (https://physicscatalyst.com/graduation/teaching-definition).

The concept of effective teaching is better understood by studying the models of instruction that capture and define what it is that an effective teacher knows and does, that is, a set of behaviors that an effective teacher incorporates into his/her daily professional practice. These involve a deep understanding of subject matter, learning theory and learner differences, planning, classroom instructional strategies, knowing individual learners, and assessment of their understanding and proficiency with learning outcomes (Barry, 2010, as cited in Unubi \& Akonti, 2017). Similarly, David (1998) remarked that effective teaching is the result when the teacher continually carries on some action research in order to improve teaching and learning. Action research here simply means being vigilant and aware of one's teaching and learning in the language classroom. Furthermore, 
Dunne \& Wragg (1994) stated that although it is not easy to define exactly what different people might mean by the term effective, teachers have always needed a wide range of subject knowledge and a large repertoire of professional skills. Teaching young children to read and write, to understand the world around them, to grasp and be able to apply fundamental mathematical and scientific principles, to use their developing intelligence and imagination, to live and work harmoniously with others, all require an effective teacher. Etymologically, the word education is derived from three Latin words educare, educere and educatum. While educare means 'to bring up' or 'to nourish', educere means 'to bring forth' or 'to draw out', and educatum means the act of teaching. An analysis of these words reveal that education aims at providing a learner or a child a nourishing environment to bring out and develop the latent potentiality hidden inside them. In view of this, Kumar \& Ahmad (2007-2008) defined education as a purposive, conscious or unconscious, psychological, sociological, scientific and philosophical process, which brings about the development of the individual to the fullest extent and also the maximum development of society in such a way that both enjoy maximum happiness and prosperity. In Short, education is the development of individual according to his needs and demands of society, of which he is an integral part. In the words of Naziev (2017), "Not so long ago in the USSR and Russia, we have approximately the following definition of education: 'Education is the socially organized and regulated process of continuous transference of socially significant experience from the previous generations to the followings, and that the main way to receive an education is to take a course of training in the system of educational institutions"' (p. 1).

\subsection{Empirical Review}

Incontrovertibly, a number of studies on effective teaching that are relevant and related to the current research have been carried out previously both locally and internationally by other language scholars. Some of them are outlined below:

In a study entitled "Teaching Igala and English languages effectively in primary schools in Igala land", Unubi \& Akonti (2017) pointed out the obvious fact that many pupils in Igala land can neither write and spell simple Igala names or words properly nor construct simple sentences in English correctly. They stated that although pupils' attitude to study is a contributory factor on one hand, the teacher, on the other, is also responsible because there are some of them who are knowledgeable or brilliant in their subject areas but they lack teaching ability, and as such, even when they teach, no matter how they do it, learners find it extremely difficult to understand what they teach. Therefore, the teaching cannot provoke any tangible and visible change in the learning behavior or behavioral knowledge of the learner. The study concluded that if teaching must be done effectively, and if it must produce excellent outcome of change in learning behavior of the learner in such a way that the teacher, the learner and the guardians or parents of the learner could feel fulfilled and satisfied, both the teacher and the learner must be real partners in progress.

While discussing what makes for effective teaching, David (2017), in a study entitled "Effective teaching and learning strategies in the language classroom", asserted that effective teaching and effective learning take place when a number of efficient and effective teaching strategies are in place and used. She also highlighted the importance of feedback in the classroom because teaching must be seen in the same light as communicating, as the teacher has to disseminate some information to the receiver, and in this case the students or learners. The message that is transmitted to the receiver must be understood by the receiver. And at the heart of effective teaching there should be an ongoing process of ensuring that what the teacher has said is what learners have understood. In view of this, she added that when students inform the teacher of what they have understood from them, the effective teacher should make use of the information. With the help of this feedback information, the teacher should determine what is going right or wrong with the ways, methods and procedures he has used or uses to transfer information. He can consequently improve on his teaching techniques. The researcher observed that the result of such continuous and intense monitoring of student understanding is that students are provided with sequential, consistent and formative feedback to clarify doubts and misunderstandings.

In their research on "Effective teaching", Dunne \& Wragg (1994) aimed to help both newcomers and experienced professionals gain further insights into their own teaching and that of others. It is also to help teachers improve on their own classroom practice because teaching is a set of craft skills, values, beliefs and practices that can be added to and improved upon at all stages. The 
researchers observed that there are many factors which combine to demand from teachers ever higher levels of professional competence. These include the rapid growth in the acquisition of knowledge, the changing nature not only of adult employment, but also of recreation and leisure, the increased public pressure for accountability, the development of new forms of educational and information technology, and the broadening role of the primary teacher. In combination they represent an overwhelming pressure for improvement by all practitioners, even the many who already manifest a high degree of skill in the classroom. The writers concluded that there is no favoring of a single approach to teaching, therefore, even though we often put forward models we have ourselves developed, the emphasis is on teachers exploring the issues, considering alternatives, trying out ideas and then finding their own best way forward in the light of their own experience and that of others.

\section{Research Method}

The nature of the present study, by design, is within the purview of qualitative research. According to The American Psychological Association (APA, 2019), qualitative research refers to scientific practices that are used to generate knowledge about human experience and/or action, including social processes. One of its characteristics is that researchers analyze data using natural language (i.e., words), observations (e.g., social interactions), and/or participants' expressions (e.g., artistic presentations) rather than collecting numerical data and conducting mathematical analyses. In line with this, therefore, the researcher collected data from both primary and secondary sources. Observational examination of both teachers and learners of the English language constituted the primary source, while extant material dealing with the subject of teaching and learning of English comprised the secondary source of data. The observation mainly bordered on phonetics and phonology, that is, how some Nigerian teachers of English realize or articulate some sounds and words of the English language. They are divided into two groups - A and B, and group A is subdivided into vowels and consonants. The writer transcribed the sounds and words involved for purposes of clarity and comprehension. These sounds and words are presented along with comments on them, and we considered the comments as the analysis of the data. We also presented the charts of the vowels and consonants of English to guide us in our analysis.

\subsection{Theoretical Framework}

This study is hinged on the theory of language pedagogy (also called linguistic theory in language teaching practice). According to Stern (1983), thoughts underlying the theory of language pedagogy are subsumed in the fact that theory is implicit in the practice of language teaching. It reveals itself in the assumptions underlying practice, in the planning of a course of study (which should be done in accordance with the needs and circumstances of the learner), in the routines of the classroom, in value judgements about language teaching, and in the decisions that the language teacher has to make day by day. Embedded in the theory of language pedagogy are linguistic concepts that are indispensable in language teaching generally, which are also relevant to the teaching of the English language in language education are between issues of language analysis and use, between grammar and functional grammar, between rule statement and derivation. It also includes issues regarding emphases on writing versus speaking, passive versus active participation by learners, deductive versus inductive teaching. Some of them are hereby enumerated and discussed in brief, as follows: (i) Traditional Grammar-based teaching; (ii) Structural Linguistics; (iii) Transformational Generative Grammar and Communicative Competence; (iv) FunctionalNotional Concepts; and (v) The Concept of variety within languages.

A careful assessment of this theory reveals its appropriacy to this study because it captures all the components of language teaching, including that of phonetics and phonology as also applicable to the teaching of the English language, which is our focal point here. This, we will describe and analyze using data because data is considered as a tool with which linguists appraise any language and its use by a particular speech community scientifically with a view to arriving at valid conclusions. 


\section{Findings and Discussion}

In the course of this research, especially from the data presented (including the sound system of English) and discussed below, which were based on observation, we discovered the following: (i) the vowel and consonant sounds that pose pronunciation challenge to Nigerians (teachers and learners) are non-existent in the sound systems of their local languages; (ii) the English language teachers in Nigeria are not 'working on themselves' enough to enable them to overcome this pronunciation challenge posed to them by these 'alien sounds'; and (iii) the teaching of the English language in Nigeria is not patterned after the Nigerian English (NE) but the British English (BrE), and as such, it is necessary they acquaint themselves with the alien sounds and teach the language accordingly to ensure effectiveness at all levels of education in Nigeria.

As mentioned before, the data for discussion here comprise some phonetic sounds and words in the English language as often realized by some Nigerian teachers and learners, constituted both primary and secondary sources of data for the study. These are divided into two groups - A and B, and group A is further divided into vowels and consonants, as follows:

\subsection{Group A: Some Sounds of English as Pronounced by Some Nigerian Teachers and Learners}

1) Vowels

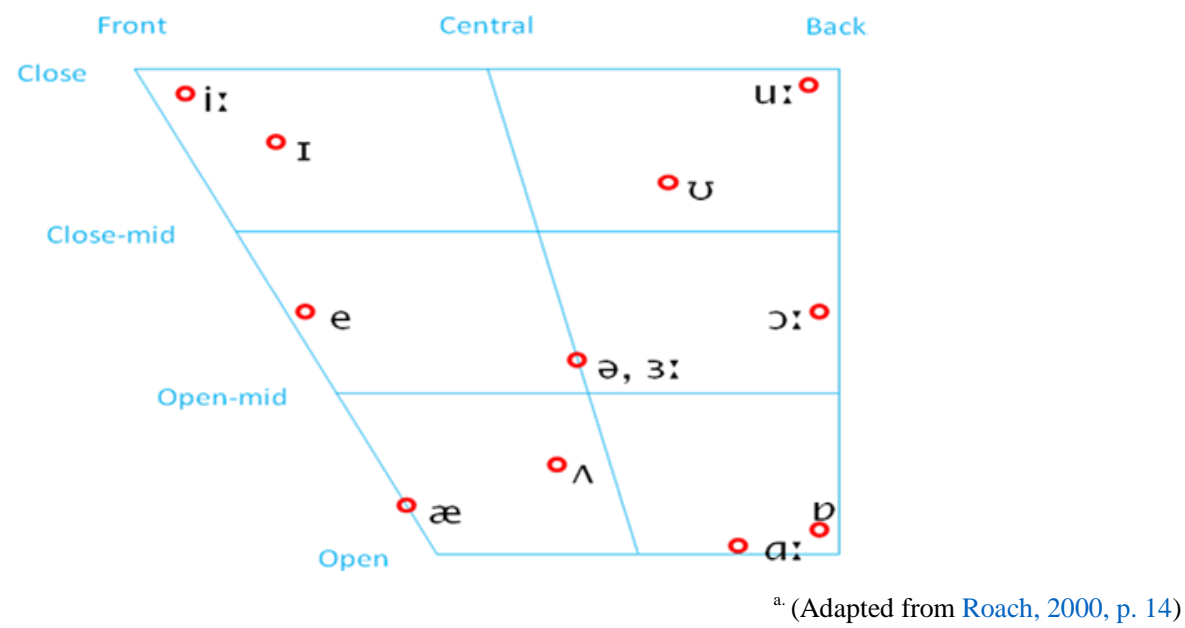

Fig. 1. Chart of English Vowel Sounds

Here we start with the monophthongs or primary cardinal vowels (note also that both diphthongs and triphthongs originate from this chart). The long mid vowel /3:/ is realized as $/ \mathrm{p} /$ and $/ \mathrm{a} /$ respectively so that first /f3:st/ becomes /fpst/, and birth /bz: $\theta /$ metamorphoses to /bat/. Furthermore, the mid unstressed vowel (schwa)/ə/, which usually appears in an unstressed syllable, is stressed and realized as $/ \mathrm{a} /$ and $/ \mathrm{p} /$ depending on the spelling such that better /beto/ is pronounced as $/ \mathrm{beta} /$, while doctor $/ \mathrm{dpkt} /$ transmutes to $/ \mathrm{dpkt} /$. The open-mid unrounded vowel $/ \mathrm{N} /$ becomes rounded and articulated as $/ \mathrm{p} /$ insomuch that under $/ \Lambda \mathrm{nd} /$ is realized as $/ \mathrm{pnda} /$. Sometimes no distinction between the close-mid front vowels /e/ and $/ \varepsilon /$ so that men $/ \mathrm{men} /$ becomes /men (note that transcriptions in some English dictionaries do not also differentiate between the two vowel sounds). Moreover, the long high back vowel /u:/ and its short counterpart / / are rarely distinguished in speech, and as such, are used interchangeably, and lastly, the same is the case with the long high front vowel /i:/ as well as its short high front type /I/. As for the diphthongs, /ra/ is pronounced as /ra/ so that fear /fiə/ becomes /fra/, and sometimes, /Iə/ and /eə/ are used interchangeably in such a way that share / $\mathrm{fe} /$ becomes / $/ \mathrm{ra} /$. In most cases, if not all, /eI/ is monophthongized in articulation as /e/ such that late /leit/ becomes /let/. Similarly, /əo/ and / $/ \mathrm{\partial} /$ are realized as monophthongal vowels /o/ and / $/ \mathrm{J}$, and consequently, own /əon/ and poor /pøə/ become /on/ and /po/. Since the diphthongs /ei/ and /əo/ are monophthongized as /e/ and /o/ respectively, the same is applicable to the triphthongs /erə/ and /əvə/. The latter is diphthongized as /ea/ while the former as /oa/ so that layer /lero/ becomes /lea/ and mower /məvə/ is now /moa/ (see Idowu, 2019 for more detail). 
Table 1. Chart of English Consonant Sounds

\begin{tabular}{|c|c|c|c|c|c|c|c|c|c|c|}
\hline $\begin{array}{c}\text { Place } \rightarrow \\
\text { Manner } \downarrow\end{array}$ & Bilabial & $\begin{array}{l}\text { Labio- } \\
\text { dental }\end{array}$ & Dental & Alv & lar & $\begin{array}{l}\text { Palato- } \\
\text { alveolar }\end{array}$ & Palatal & & & Glottal \\
\hline Plosive & $\mathrm{p}$ & & & $\mathrm{t}$ & $\mathrm{d}$ & & & $\mathrm{k}$ & $\mathrm{g}$ & \\
\hline $\begin{array}{l}\text { Fricative } \\
\text { Affricate }\end{array}$ & & $\mathrm{v}$ & ð & $\mathrm{s}$ & $\mathrm{z}$ & $\begin{array}{ll}\int_{t} & 3 \\
d\end{array}$ & & & & $\mathrm{~h}$ \\
\hline Nasal & $\mathrm{m}$ & & & & $\mathrm{n}$ & & & & $\eta$ & \\
\hline Lateral & & & & & 1 & & & & & \\
\hline Approximant & $\mathrm{w}$ & & & & & $\mathrm{r}$ & $\mathrm{j}$ & & & \\
\hline
\end{tabular}

The voiceless bilabial plosive /p/ is sometimes realized as the voiceless labiodental fricative /f/ so that people /pi:pl/ becomes /fi:fl/. In the same vein, the voiced labiodental fricative /v/ is realized as the voiceless labiodental fricative /f/ such that vast /væst/ becomes /fast/. Furthermore, the dental fricatives $/ \theta /$ and $/ \delta /$ are articulated as the voiceless and voiced alveolar plosives $/ t /$ and $/ d /$, and as such, faith /fei $\theta /$ becomes /fet/ while leather /leðə/ is /leda/. The voiced alveolar fricative $/ \mathrm{z} / \mathrm{is}$ pronounced as the palato-alveolar affricate /dz/ such that zeal /zi:V/ becomes /dzi:V. Similarly, the voiceless and the voiced palato-alveolar fricatives $/ \mathrm{J} /$ and $/ 3 /$ are realized as the voiceless fricative /s/ and the voiced palatal approximant $/ \mathrm{j} /$ respectively to the extent that shall $/ / \mathrm{fæl} / \mathrm{becomes} / \mathrm{sal} /$ and treasure /trezə/ is /trejo/. And sometimes, the alveolar approximant $/ \mathrm{r} /$ is realized as the alveolar lateral /// so that ruler /ru:lə/ metamorphoses to /lula/ (see Idowu, 2019 for more detail).

\subsection{Group B: Some Words of English as Pronounced by Some Nigerian Teachers and Learners}

Commenting on how pronunciation of some English words by some Nigerian users of English differ from that of the Received Pronunciation (RP), Ejembi (2019) blamed this phenomenon on the

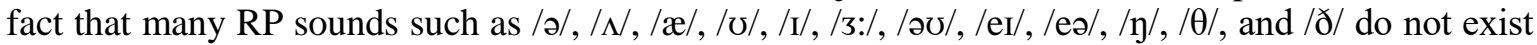
in Nigerian English (NE). He cited the following examples:

\section{WORDS}

(a) Doctor

(b) Man

(c) Good

(d) Kiss

(e) Learn

(f) Made

(g) Go

(h) Fare

(i) Through

(j) Weather

(k) Singing

(l) Measure

RP
/dpktə/
/mæn/
/gud/
/kis/
/ls:n/
/meId/
/gəo/
/feə/
/Oru:/
/wedə/
/sını//
/mezə/

NE

/dpkts/

/man/

/gud/

/kis/

/len/

/med/

/go/

$/ \mathrm{f} \varepsilon /$

/tru:/

/weda/

/singin/

/meyp/ (pp. 5-6).

While discussing consonant deletion at the coda in a consonant cluster by some Nigerian users of English in speech, Unubi (2019a) asserted that such articulation has not only affected the English words concerned semantically (in terms of comprehension or intelligibility) but also altered them orthographically and phonetically. The words are embedded in sentences but clearly highlighted. Here are some of them:

1. The studen is sick. [stju:dən] instead of /stju:dənt/.

2. Please do not stop my movemen. [mu:v.mən] instead of /mu:v.mənt/.

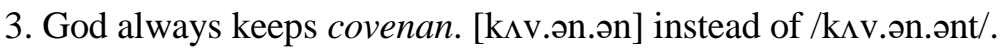

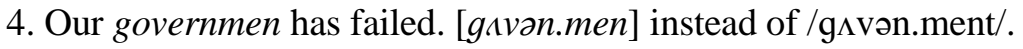

5. Let us go and plan cassava. [pla:n] instead of /pla:nt/.

6. Please repen of your sin today. [ripen] instead of /ripent/. 
7. I had lef before you came. [lef] instead of /left/.

8. INEC is planning to shif the 2019 elections. [/If] instead of $/ \mathrm{fIft} /$.

9. The shaf of his car had been removed. [fa:f] instead of / $\mathrm{a}: \mathrm{ft} /$.

10. What is my faul in this matter? [fo:l] instead of /fo:lt/.

11. Please let the secon person come in. [sekən] instead of /sekənd/.

12. It is very $\mathrm{col}$ in Jos at the moment. [kavl] instead of /kəold/ (pp. 23-24).

What is the factor responsible for this phenomenon? Well, the reason for this 'unique pattern' of realizing some of the sounds and words of the English language as presented in this study is not hard to find. Nigeria is a multilingual society with about five hundred known individual languages (Esizimetor, 2010) and (Blench, 2017). If we should present the sound systems (both vowels and consonants) of all the languages of Nigeria here, we would discover that some of these vowels and consonant sounds of English, especially the ones that are problematic in realization to the Nigerian users of English (both teachers and learners) are apparently non-existent. In view of this obvious deficiency, we tend to use 'what we have to get what we do not have but needed' as Nigerians, that is, we use the sounds we have in our various languages and force them on the English sounds that are not available in ours, since we must use the English language. A meticulous consideration of the sounds, words as well as the following comments on them as presented above, one would discover that the 'pronunciation uniqueness' therein are peculiar to particular tribes belonging to some Nigerian languages. Commenting along this line, Runsewe (1986) as cited in Idowu (2019) explained that scholars have used the locality from which speakers come as a label for the type of English they speak. In other words, by listening to spoken English of a Nigerian (whether a teacher or a learner), it is usually possible to envisage the part of the country such a person came from and this is because the accents of most speakers are often very heavily spiced with indexical features of the mother tongue of the speakers. To this end, we have Hausa English, Yoruba English, Ibo English, Igala English, Efik English, Urhobo English, Tiv English, etc. all constituting Nigerian English. In a milder manner, Idowu (2019) observed that English pronunciation teaching in Nigeria should acknowledge this as a variation (Nigerian English) rather than a deviance (p. 329).

However, the pertinent question here is that: is English teaching at all levels of education (primary, secondary and tertiary) in Nigeria patterned after the British English (BrE) or the Nigerian English (NE)? Well, Idowu (2019) answered this question when he said "Currently, in Nigeria, the model for teaching English pronunciation remains the Standard British English Pronunciation while Nigerian English is not considered as a possible source of classroom norms but as a substandard variety of British English by key stakeholders and teachers (p. 328). Since we find ourselves in this situation as teachers, what do we do then? Idowu (2019) further stated that English teachers in

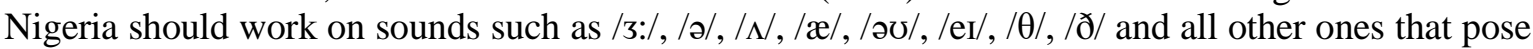
pronunciation challenge to them. In fact, Unubi (2019) called this drilling when he advised that both Nigerian teachers and learners of English should work on themselves by getting acquainted with the sound systems of English and their individual languages to see the areas of differences, mark the sounds that pose pronunciation challenge to them, and devise a means, perhaps, by constant drilling to overcoming the challenge. Definitely, this will bring about effectiveness in the teaching of the English language in Nigeria, which in turn will lead to desirable learning outcomes describable as satisfactory to the learner, teacher, parents, government and other stakeholders at all levels of education in the country.

\section{Conclusion}

This research is an attempt at describing effective teaching of the English language in Nigeria, bearing in mind the fact that no research is conclusive or perfect anywhere across the globe. This is because language is dynamic and so changes are bound to occur intermittently. From our analysis, it is evident that if English teachers in Nigeria should work on themselves concerning these sounds -

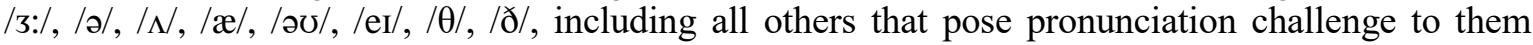
through drilling, the result will be effective teaching and learning outcomes that can be described as satisfactory to the learners, teachers, parents and other stakeholders at all levels of education in the country. 


\subsection{Contributions of this Study}

This research, unmistakably, contributes to scholarship in English language education or educational linguistics as follows: firstly, the sounds (both vowels and consonants) that pose pronunciation challenge to both teachers and learners are non-existent in the sound systems of their local languages, and that if only they work on themselves to master these sounds, the result is effective teaching of the English language in Nigeria. Secondly, as an empirical study with the theory of language pedagogy as its framework and observation method as used in Philipps (2009) and Altuna \& Basurto (2013), it has added to the existing studies in both linguistics and education.

\subsection{Suggestions for Further Research}

Since no research can be described as perfect, it means that this study is limited and requires further studies. Truly, more studies on the necessity of effective teaching of the English language in Nigeria using different approaches are still required. In addition, studies on effective learning outcomes on the part of the learners of the English language should be intensified. Lastly, the Nigerian government should encourage linguists to teach all the indigenous languages of Nigeria at primary and secondary levels of education. This, indeed, will lead to the production and comparison of the sound systems of all Nigerian languages with that of English for effective teaching and learning of English.

\section{References}

Altuna, O., \& Basurto, A. (2013). A guide to language use observation: Survey methods. Administration of the Autonomous Community of the Basque Country Ministry for Education, Linguistic Policy and Culture.

American Psychological Association. (2019). Publication manual of the American Psychological Association (7th ed.).

Blench, R. (2017). Nigeria: Africa's most linguistically diverse country. Addis Ababa University. https://Nigeria_Africa_s_most_linguistically_div.pdf

David, M. K. (1998). Effective teaching and learning strategies in the language classroom. The English Teacher, 28, 1-8.

Dunne, R., \& Wragg, T. (1994). Effective teaching. Routledge.

Ejembi, O. (2019). Towards a functional pedagogical approach to language: A critical argument. International Journal of Advance Research and Innovative Ideas in Education, 5(6), 1-7.

Esizimetor, D. O. (2009, July 8-9). Historical development of Naijá [Proceedings of the conference on Nigerian pidgin]. University of Ibadan, Nigeria.

Idowu, F. O. (2019). Pronunciation intelligibility of Nigerian Speakers of English. (Doctoral Dissertation, University of Roehampton, London]. https://pure.roehampton.ac.uk/ws/portalfiles/portal/2418566/Pronunciation_Intelligibility_of_Nigerian_S peakers_of_English.pdf

Kumar, S., \& Ahmad, S. (2007-2008). [Lecture notes on meaning, aims and process of education (Lesson 1)]. School of Open Learning, University of Delhi. https://pdfs.semanticscholar.org/ec0b/b4e95baef9644b46b0a8d81c17fcbe14eb0f.pdf

Naziev, A. (2017). What is an education? Ryazan State University, Ryazan, Russian Federation. https://www.researchgate.net > 317545698_What_is_an_education.

Philipps, S. (2009). The relationship between teacher education, teacher cognition and classroom practice in language teaching: A case study of MA students' beliefs about grammar teaching. (Doctoral Dissertation, The University of Leeds School of Education). http://etheses.whiterose.ac.uk/715/1/uk_bl_ethos_496521.pdf

Roach, P. (2000). English phonetics and phonology (2nd ed.). Cambridge University Press.

Smith, M. K. (2018). What is teaching? The encyclopedia of pedagogy and informal education. https://infed.org/mobi/what-is-teaching/ 
Stern, H. H. (1983). Fundamental concepts of language teaching. Oxford University Press.

Unubi, S. A., \& Bello, C. E. (2019). Essential linguistic knowledge on the French and English languages. Global Journal of Applied, Management and Social Science, 16, 52-66.

Unubi, S. A., \& Yusuf, S. (2017). Fundamental linguistic information on English, Igala and Hausa Languages. World Wide Journal of Multidisciplinary Research and Development, 3(12), 409-419.

Unubi, S. A. \& Akonti, C. (2017). Teaching the English and Igala languages effectively in primary schools in Igala land. World Wide Journal of Multidisciplinary Research and Development, 3(12), 420-424.

Unubi, S. A. (2019). Consonant deletion in the speech of English-Platoid bilinguals. Advances in Image and Video Processing, 7(1), 19-33. http://dx.doi.org/10.14738/aivp.71.6069

Unubi, S. A. (2019). A contrastive study of English and Igala segmental phonemes: Implications for ESL teachers and learners. Journal of Biomedical Engineering and Medical Imaging, 6(6), 31-43. http://dx.doi.org/10.14738/jbemi.66.8012 